\title{
Insurance of the costs of pharmaceuticals in the Netherlands: a law and economics perspective
}

Citation for published version (APA):

Faure, M. G., \& Philipsen, N. J. (2002). Insurance of the costs of pharmaceuticals in the Netherlands: a law and economics perspective. Geneva Papers on Risk and Insurance Theory, 27(4), 609-625. https://doi.org/10.1111/1468-0440.00196

Document status and date:

Published: 01/01/2002

DOI:

10.1111/1468-0440.00196

Document Version:

Publisher's PDF, also known as Version of record

Document license:

Taverne

Please check the document version of this publication:

- A submitted manuscript is the version of the article upon submission and before peer-review. There can be important differences between the submitted version and the official published version of record.

People interested in the research are advised to contact the author for the final version of the publication, or visit the DOI to the publisher's website.

- The final author version and the galley proof are versions of the publication after peer review.

- The final published version features the final layout of the paper including the volume, issue and page numbers.

Link to publication

\footnotetext{
General rights rights.

- You may freely distribute the URL identifying the publication in the public portal. please follow below link for the End User Agreement:

www.umlib.nl/taverne-license

Take down policy

If you believe that this document breaches copyright please contact us at:

repository@maastrichtuniversity.nl

providing details and we will investigate your claim.
}

Copyright and moral rights for the publications made accessible in the public portal are retained by the authors and/or other copyright owners and it is a condition of accessing publications that users recognise and abide by the legal requirements associated with these

- Users may download and print one copy of any publication from the public portal for the purpose of private study or research.

- You may not further distribute the material or use it for any profit-making activity or commercial gain

If the publication is distributed under the terms of Article $25 \mathrm{fa}$ of the Dutch Copyright Act, indicated by the "Taverne" license above, 


\title{
Insurance of the Costs of Pharmaceuticals in the Netherlands: A Law and Economics Perspective
}

\author{
by N.J. Philipsen and M.G. Faure*
}

\section{Introduction}

In this paper we address price regulation and insurance for pharmaceuticals in the Netherlands using a law and economics approach. We analyse, qualitatively, the regulatory framework and insurance for pharmaceuticals. First, we investigate how drugs are priced. In the Netherlands, healthcare insurance has an important influence on the price of drugs. After that we address how healthcare insurance compensates patients requiring pharmaceuticals. In addition, we examine the various actors in the drug distribution market with a specific focus on the regulation of pharmacists ${ }^{1}$ and the way in which their income (derived from the pharmacist's fee) is influenced by the insurance mechanism.

A crucial question is of course whether the existing system of insurance for pharmaceuticals in the Netherlands is efficient. In that respect, we investigate whether this insurance scheme corresponds more to the principles of social security or to the principles of private insurance. Indeed, the question arises as to the way in which principles of private insurance (such as a risk-related premium setting and risk differentiation) are also applied in social insurance schemes with respect to pharmaceuticals. Further to this, we examine whether the current financing system provides optimal incentives to control demand (are instruments used to control overconsumption?) and to control supply (are sufficient incentives provided, e.g., for pharmacists to seek cheaper alternatives?). Finally, we examine how more use could be made of market forces to increase the efficiency of the current system of insurance for pharmaceuticals.

Although the paper provides a case study of regulation in the Netherlands and reviews the Dutch market for pharmaceuticals, its findings are relevant to other areas. Indeed, the question of how the regulatory and insurance frameworks affect the optimal allocation of resources, with respect to the financing of pharmaceuticals, will be addressed.

This paper is structured as follows: after this introduction (section 1), we discuss the regulation of the price of pharmaceuticals and the pharmacist's fee. We then examine the system of finance and the intervention of healthcare insurers in the market in section 3 . In section 4 , we focus on the extent to which this system can be considered efficient and identify causes of potential inefficiencies. The paper ends with a few concluding remarks outlined in section 5 .

* METRO Institute for Transnational Legal Research, Maastricht University, The Netherlands. We are grateful to the participants at the 9th joint seminar of the European Association of Law and Economics and the Geneva Association for the Study of Risk and Insurance (Copenhagen, 5-6 April 2001), where we presented an earlier draft of this paper.

1 We analyse the regulation of pharmacists, both in the Netherlands and in Belgium, in more detail in another paper: see Philipsen and Faure (2002). 


\section{Prices and fees}

How is the price of pharmaceutical products fixed in the Netherlands? To a large extent price depends on the cost of production and the market situation. As this is a law and economics paper, we will not go into these aspects of price-setting, but focus on how the law, and more specifically regulations, affect the price of pharmaceuticals. Several regulatory aspects need to be considered, namely: how regulatory action affects the price of drugs (section 2.1) and how regulations concerning the pharmaceutical profession impact on the price of drugs (section 2.2). The latter is an important aspect as pharmacists are the people who are almost exclusively competent to deliver drugs in the Netherlands.

\subsection{The price of drugs}

In the Netherlands drugs are divided into two categories: WTG and non-WTG. WTG drugs are drugs that are available only at the pharmacy and which therefore fall under the Health Care Charges Act. In order to obtain these drugs, patients always need a prescription from a physician or specialist. Non-WTG drugs may also be supplied in outlets other than pharmacies, such as chemists or sometimes even a special supermarket counter, provided that a chemist or pharmacist plays a supervisory role at such a counter. In 2000, of all prescription drugs supplied by community pharmacies, 86.1 per cent were WTG drugs. ${ }^{2}$

All WTG drugs registered in the Netherlands are included in the so-called taxe. ${ }^{3}$ The taxe is a list of drugs registered in the Netherlands; it is published every month on the basis of the $\mathrm{CTG}^{4}$ tariff orders. The CTG tariff orders determine the maximum amount that pharmacists may charge to compensate for their purchase cost. In practice, the CTG tariff orders allow the purchase cost of drugs to be recovered fully by the pharmacist. ${ }^{5}$ However, only the prices reported by drug producers and importers are included in the taxe and not the prices of those who actually supply the drugs to pharmacists in the vast majority of cases, the wholesalers. This of course leads to resale price maintenance. Moreover, because pharmacists operate on the basis of a "pharmacy purchase price = pharmacy retail price" principle, the producer or importer (indirectly) determines the final retail price of the drug. ${ }^{6}$

Once a drug has been included in the taxe, the only way a drug producer can compete is by using the margin between the cost price (i.e. the actual cost of producing the drug) and the pharmacy purchase price as fixed in the taxe. This margin is used by producers to provide bonuses and discounts to pharmacists to persuade them to sell their drugs instead of those of competitors. $^{7}$ Thus, in practice the taxe price is often not the price paid by the pharmacist to the drug producer or wholesaler. However, the patient or insurer does not derive any benefits from these practices, because the regulated taxe price is the price that pharmacists charge patients.

In the Netherlands pharmaceutical products prescribed by a physician and dispensed by

2 SFK (2001), p. 37.

3 Officially called the taxe of Z-index. Z-index belongs to the Dutch pharmacists'association KNMP.

4 Health Charges Board (College Tarieven Gezondheidszorg). Among the tasks of this government watchdog body are the supervision and registration of all drugs (proprietary, parallel imported and generic) that have been put into circulation.

5 MDW (1999), p. 67.

6 When drug producers make price decisions they have to take into account the provisions in the Drug Prices Act and the Drug Reimbursement System,which is described below.

7 Ministerie van Volksgezondheid, Welzijn en Sport, (1999), p. 28. 
a pharmacy are usually either paid by the patient or reimbursed (fully or in part) by the health insurance. Hence, it is in the interest of insurers to keep consumption of pharmaceutical products within a reasonable limit. Although insurers can deviate from the taxe prices when reimbursing pharmacists, they rarely do this because of the administrative complexity of diversifying prices. In the current situation they only have to deal with one price per drug.

The pharmaceutical industry's scope for competing on the basis of price is limited once prices have been set in the taxe; to offset this, drug producers resort to bonuses and discounts. In principle, industry sets prices taking into account obvious elements such as the cost of production and the cost of research and development. Assuming that the drug enjoys intellectual property right protection, the producer will be able to set his price in such a way as to include a profit to compensate for development costs. However, prices can obviously not be set at random, there may be competition from other pharmaceutical products with the same or similar effects and prices are controlled by government regulation. Government regulation is necessary given that the (largely publicly financed) ${ }^{8}$ healthcare system in the Netherlands covers pharmaceutical products. To control the public budget it is in the interest of the government to control drug prices. This occurs in various ways. Firstly, the Drug Prices Act ${ }^{9}$ of 1996 grants the Minister of Public Health the right to fix a maximum price for registered drugs that are available to all. This price, which has already been fixed for the vast majority of drugs, is determined by the average price in neighbouring countries, including Belgium, France, Germany and the United Kingdom. It has to be reviewed at least twice a year. ${ }^{10}$ Secondly, the Drugs Reimbursement System (DRS) (Geneesmiddelenvergoedingssysteem), the statutory insured drug package introduced in 1991, strongly influences the price of drugs. Under the DRS, therapeutic drugs, which are mutually interchangeable, are clustered by the Ministry of Public Health. For every cluster the Ministry defines a reimbursement limit: the amount that is reimbursed to pharmacists. If the price of a certain drug is higher than this limit, the price difference must be borne by patients using the drug instead of the health insurer. This price difference functions as a deductible. As a result, drug producers do not set prices above the reimbursement limit. Many producers fix their prices exactly at or just below the DRS price limit.

\subsection{The pharmacist's fee}

What is the fee a pharmacist receives for his or her services which include drug dispensing, customer advice and medication surveillance? Regulations in the Netherlands are as follows: for every drug dispensed on prescription the pharmacist receives a fixed fee (receptregelvergoeding), which in 2001 was HFL 12.50 ( $€$ 5.67), irrespective of the price or the quantity of the drug. The fixed fee is updated each year by the CTG, ${ }^{11}$ which takes into consideration developments in the number of dispensed WTG drugs per year. The fixed fee pharmacists receive for supplying WTG drugs is not related to the cost of the product. On the contrary, the fee is fixed per prescription and does not depend on whether the medicine costs $€ 5$ or $€ 50$. The fee also does not depend on the prescribed amount. The result is that in the

8 See section 3.2 .

9 Wet van 25 januari 1996 houdende regels omtrent de vaststelling van maximumprijzen voor geneesmiddelen (Wet Geneesmiddelenprijzen), Stb. 90, 1996.

10 Drug Prices Act, Article 3.

11 Note 4 above. 
Netherlands tariffs for WTG drugs do not, or only barely, differ between pharmacies. In section 2.1 above, we explained that the purchase price of the pharmacy as defined in the taxe determines the level of refund pharmacists receive from insurers. Therefore, pharmaceuticals in the Netherlands are sold at almost the same price at which they are purchased. Pharmacists in the Netherlands are not considered to be retailers and hence do not make a living from selling drugs. On the contrary, they are considered to be "professionals" and therefore receive a fixed fee for services performed.

There is also a substitution measure that makes up part of the pharmacist's fee, albeit a relatively small part compared to the fixed fee. The substitution measure takes into account the fact that a prescriber (e.g., a physician or specialist) in principle has to prescribe under the substance name and not under the brand name. This so-called incentive measure means that a pharmacist is allowed to keep one-third of the price difference between a proprietary drug and an equivalent parallel-imported ${ }^{12}$ or generic drug. ${ }^{13}$ The final saving for the insurer is then twice as high as the incentive revenue of the pharmacist. The basic idea obviously is that this should give the pharmacists incentives to prescribe (cheaper) generic or parallel-imported drugs. However, the price differences between branded and generic drugs are becoming smaller and smaller due to the oppressive effect the Drug Prices Act and the Drug Reimbursement System exert on the price level. The possibilities for parallel imports therefore have also decreased drastically. Revenue earned by pharmacists through the incentive measure is often lower than the amount they could earn by accepting rebates for branded drugs, so the incentive measure loses its appeal relative to the bonuses and discounts offered by drug producers and wholesalers. ${ }^{14}$ In 1999, the government incorporated the average incentive revenue per prescribed WTG drug of $€ 0.18$ in the fixed fee. ${ }^{15}$ Since then pharmacists have been more or less obliged to compensate for this. The fixed fee and the incentive measure came into force on 1 January $1988 .{ }^{16}$

Pharmacists also receive revenues from the sale of non-WTG drugs and medical devices (such products may be sold by chemists as well). The average profit margin on these products lies between 20 and 30 per cent. ${ }^{17}$ Just like the taxe for WTG drugs, the retail and purchase prices of these products are included in a list that is issued monthly by the KNMP. Contrary to the case of WTG drugs, there is some price competition between pharmacies in this field. However, since the sale of WTG drugs makes up (by far) the largest part of the turnover in pharmacies, it concerns relatively small amounts of money. ${ }^{18}$ Moreover, in calculating the fixed fee the CTG takes the average revenues pharmacists obtain from trade activities, other than the sale of WTG drugs, into account as well.

12 Branded drugs that are imported from other E.U. countries, where prices are lower than in the Netherlands, outside the manufacturer's official distribution channel. See SFK (1999, p. 21).

13 This incentive measure is, like the fixed fee and the taxe, a result of the CTG tariff orders. See also note 4 above.

14 Bogin (1999), p. 11.

15 With this a saving of $€ 17.7$ million was intended. The underlying idea was that it is an elementary duty of a pharmacist to dispense efficiently and that therefore the income from the incentive measure should be included in the calculations of the fixed fee (Ministerie van Volksgezondheid, Welzijn en Sport, Aanwijzing stimulansopbrengst in de tarieven farmaceutische zorg, 29 June, 1999).

16 RVZ (1998), p. 96.

17 KNMP (1998), p. 41.

18 Split up per product category, 85 per cent of the turnover of an average pharmacy in 1998 was determined by WTG drugs, against 7 per cent by non-WTG drugs, 4 per cent by medical devices and 4 per cent by OTC. See SFK (1999, p. 52). 
It appears that the scope for pharmacists to compete is not limited to pricing policy. Quite the contrary, the government regulates the entire market, with the exception of income earned from activities other than the sale of WTG drugs.

\section{The system of finance and the intervention of healthcare insurers}

Having described in the previous section how prices for pharmaceuticals are fixed in the Netherlands, we will now turn to the insurance aspect and address the question of how the consumption of these pharmaceuticals is financed. First, we provide a short overview of available health insurance schemes, as applicable to pharmaceuticals (3.1). Then we will address the question of how this system is financed (3.2). This will allow us to examine the system of pricing and financing of pharmaceuticals from an economic perspective in the following section.

\subsection{A short overview of the Dutch health insurance system for pharmaceuticals}

In general, the Dutch health insurance system is divided into three categories that correspond to a classification system of healthcare. ${ }^{19}$ The first category concerns medical expenses associated with long-term care and high-cost treatment, like hospital treatment and home care. For these costs there is a mandatory public insurance scheme in the Netherlands called the Exceptional Medical Expenses Act, ${ }^{20}$ which is financed by income-dependent contributions and government funds. The second category of normal and necessary medical care, e.g., visits to a general practitioner and hospital nursing, is the subject of this section, because pharmaceutical services also belong in this category. The medical costs of this category of patients can be publicly or privately insured, as we will see below. The third category consists of medical expenses associated with forms of care regarded as being less essential, which are therefore predominantly covered by (voluntary) private insurance (e.g., most forms of dental care). The amount of medical care provided that is not funded by one of these insurance schemes is negligible. ${ }^{21}$

In the Netherlands health insurance with respect to normal and essential medical care is provided both by public health insurance funds and by private insurers. ${ }^{22}$ According to the Health Insurance Act (HIA), ${ }^{23}$ public insurance is compulsory for individuals meeting the criteria set by the legislation. Everyone meeting the criteria is automatically insured and must pay the statutory contributions, whether or not they wish to make use of the benefits offered. These contributions are to a large extent income dependent. The most important criterion is the income ceiling (in 2002 everyone with an income of up to $€ 30,700$ fell under the HIA), but also people who receive unemployment benefits fall under the HIA. ${ }^{24}$ Insurance cover is

19 Recently the Dutch Government has proposed a number of changes in the health insurance system. See, e.g., Ministerie van Volksgezondheid, Welzijn en Sport (2002, pp. 12-13). Here we discuss the current system.

20 Wet van 14 december 1967 (Algemene Wet Bijzondere Ziektekosten), Stb. 655, 1967.

21 Ministry of Health, Welfare and Sport (1998), pp. 5-6.

22 There is a special (mandatory) insurance scheme for public servants other than central government officials and teaching staff, which constitutes only about 5 per cent of the market. It is not possible to deal with this specific subject within the scope of this paper. For details see Ministerie van Volksgezondheid, Welzijn en Sport (2002, Ch. 4).

23 Wet van 15 oktober 1964 (Ziekenfondswet), Stb. 392, 1964.

24 There are special rules for people over 65. See, e.g., Ministerie van Volksgezondheid, Welzijn en Sport (2002, Ch. 3). 
extended to the partner and children of the insured party, subject to some conditions. This coinsurance is free of charge. Almost two-thirds of the Dutch population is covered by the HIA; the proportion is over 64 per cent, while the privately insured account for \pm 31 per cent. ${ }^{25}$

Despite the statutory character of the HIA, individuals have to register with a health insurance fund in order to obtain benefits. This is purely an administrative procedure and does not imply entering into an insurance contract, since insurance coverage follows from legislation. Individuals can choose from a wide variety of health insurance funds; since 1992 health insurers have no longer been limited to certain regions and all health insurance funds are available nationally. ${ }^{26}$ Moreover, health insurance funds have a duty of acceptance.$^{27}$ In order to obtain medical services individuals must apply to a practitioner (e.g., a pharmacist or institution) with whom their health insurance fund has concluded a contract. People have a free choice of practitioner or institution within the group contracted by the health insurance fund. ${ }^{28}$

The system just described accounts for 64 per cent of the market. But 31 per cent of the Dutch population is insured with a private insurer. ${ }^{29}$ Although the contents of the services to be provided by the healthcare insurer are also subject to regulation, there is much more scope and freedom to negotiate the extent of coverage and corresponding premiums. In private insurance the premium is in principle risk-related (through the extent of coverage and the deductible). In practice, the higher income groups (individuals who cannot enter the HIA) take out private health insurance.

\subsection{Financing and benefits under the healthcare system}

\subsubsection{Financing}

The contribution for cover under the HIA consists of two parts: an income-related part that is collected by the government (a percentage deducted from the wage, profit, benefit or retirement pay) and a nominal (flat-rate) part, which is fixed and collected by the health insurance fund itself. Thus, Dutch public health insurance is not only characterized by risk solidarity, but also by income solidarity. In addition, the income-related contribution is partly paid by the employer. ${ }^{30}$ Apart from these contributions, public health insurance is financed from two other sources: an annually determined government grant and special transfer payments for the elderly, paid by privately insured individuals via a statutory yearly contribution on top of their nominal (insurance) contribution. With the exception of the flat-rate contribution, all these sources of funding are channelled into a general fund for health insurance, which is administered by the government.

Private health insurance is financed differently. Because private insurers do not benefit from government-collected contributions, they are completely dependent on the nominal

25 Ministerie van Volksgezondheid, Welzijn en Sport (2002), p. 9.

26 Ministerie van Volksgezondheid, Welzijn en Sport (2000), p. 36.

27 Private insurers do not have this obligation.

28 There is an exception for general practitioners: once individuals have chosen a doctor from among those who have contracts with their health insurance fund, they are registered with that specific doctor.

29 Certain categories of people, like seamen, and certain individuals entitled to cover who live outside the country are required to register with specific funds (Ministerie van Volksgezondheid, Welzijn en Sport, 2002, p. 32).

30 On average, the flat-rate contribution was NLG 216 (€ 98) per person in 1998. See Ministry of Health, Welfare and Sport (1998), p. 28. 
contributions: risk-related premiums. The premiums for private insurance differ, though not greatly, between insurance companies and are of course influenced by the size of the cover and the amount of the deductible chosen by the individual. There is no income solidarity in private health insurance, only risk solidarity. ${ }^{31}$ However, next to its "normal" health insurance policies, every private health insurer in the Netherlands is obliged to provide a so-called standard insurance as well. This standard insurance guarantees insurance cover to certain groups of people who do not fall under the HIA and therefore have to be insured privately. The government determines the premium for this standard policy. ${ }^{32}$ Private insurers are obliged to charge, in addition to the premium, two statutory contributions, which are fixed by the government. The first concerns a transfer that goes to the general fund for public insurance (because older people are over-represented in this category). The second concerns a contribution that is used to fund standard insurance. These statutory contributions are the same for every insurer. This shows that regulation seriously limits the scope for charging truly risk-related premiums in private health insurance.

\subsubsection{Benefits}

Cover under the HIA gives entitlement to benefits in kind in the form of medical treatment and care. This is different from private medical insurance, where clients are reimbursed for medical expenses incurred by themselves. With respect to pharmaceutical services, it is important to mention here that the Drugs Reimbursement System (already briefly introduced in section 2.1 above) applies. This means that the patient only gets a fixed amount reimbursed, as determined by the Drugs Reimbursement System. If he chooses a more expensive drug he will have to cover the additional costs.

In 1997, individuals insured under the HIA were also obliged to pay charges towards the cost of treatment and services. This charge was 20 per cent of the cost of treatment and services provided under the HIA, the maximum being $€ 90$ per calendar year for the insured party and persons co-insured. ${ }^{33}$ Such a charge effectively functioned as a deductible and was borne by the patient. Today, this charge no longer exists.

As far as private health care insurance is concerned, the benefits are dependent on what has been agreed between the insurer and the insured. However, as stated above, a standard insurance benefit, of which the content is fixed in regulation, has to be offered anyway. The amount and applicability of the deductible can, to a large extent, be freely negotiated in private health insurance; the size of the deductible will obviously have an influence on the premium charged.

\subsubsection{Drugs Reimbursement System}

Let us, given the scope of this paper, turn once more to the Drugs Reimbursement System (DRS) discussed above. This regulation fixes the amounts the insurer is supposed to reimburse for pharmaceuticals and hence determines the scope of the benefits. The DRS contains

31 And even here the term "solidarity" is somewhat misleading. All this means is that risks are spread between various members of a risk group. This is the solidarity which simply amounts to the risk-spreading inherent in any insurance system. Solidarity does not, however, imply that good risks should subsidise bad risks. On the contrary, risks should as much as possible be differentiated. The "solidarity" is thus limited to those insured posing a similar risk.

32 For specifics on the standard insurance, see Ministerie van Volksgezondheid, Welzijn en Sport (2002), Ch. 3.

33 Some exceptions applied, e.g., the cost of a visit to a general practitioner and costs related to childbirth. 
reimbursement limits determined by the government. These reimbursement limits are the maximum amounts that will be reimbursed to consumers by (public) health insurers for clusters of therapeutically equal drugs. New pharmaceuticals (for which there is no substitute) will only be included in the DRS if they have a clear added value ${ }^{34}$ to the drug package. In practice, new drugs are therefore often placed on a waiting list for some time before they are included in the DRS. ${ }^{35}$ The DRS was introduced in 1991 with the objective of lowering the cost of healthcare in the Netherlands. However, the DRS also limits competition, because it has a big influence on the price-setting behaviour of the drug industry. In addition, it decreases the bargaining position of insurers as they have a duty to reimburse (up to the statutory limit) every prescription drug included in the DRS. Moreover, the DRS often delays the entry of new drugs into the market, as noted above. Since private insurers have always followed the example set by the national health service (public insurance) as far as reimbursement of drugs is concerned, in practice the DRS limits apply for both the public and the private health insurance sectors.

\section{Analysis of Dutch regulations}

In this section we try to answer the crucial question posed in the introduction: is the existing system of insurance and compensation for pharmaceuticals in the Netherlands efficient? To answer this question, it is interesting to investigate how principles of private insurance are also applied to the social insurance schemes for pharmaceuticals. We will do just that, at a rather theoretical level, in section 4.1. After that we assess the economic effects of the Dutch insurance system for pharmaceuticals by analysing the finance system: does it provide incentives to control the demand and supply of drugs? We then turn to the supply side by looking to what extent the current regulatory framework, and more specifically the role of the pharmacists, ${ }^{36}$ gives incentives for providing the most effective pharmaceuticals at optimal prices (section 4.3). Finally, we look at the overall efficiency of the pricing system and insurance regulation for pharmaceuticals in the Netherlands (section 4.4).

\subsection{Principles of social security versus principles of private insurance}

In order to be able to address the question of the way in which principles of private insurance are applied to the social insurance schemes for pharmaceuticals, we first focus on the different approaches taken by private insurance and social security. This is an interesting approach: it allows us to analyse whether a publicly-financed insurance scheme for the compensation of pharmaceutical products, such as the Dutch system, can be organized in such a manner that there are efficient incentives for cost control.

If one looks at accident law, private insurance is usually linked with the concept of liability and thus with tort law. The basis of tort law, and in that respect it is clearly different from social security, is that the occurrence of damage as such is not enough to provide compensation to victims. Some other element needs to be added to grant the victim a right to

\footnotetext{
34 On the European level the Committee of Proprietary Medicinal Products carries out the assessment of "new" drugs. In the Netherlands, the added value of new drugs is judged by the Drug Assessment Board (College Beoordeling Geneesmiddelen, CBG).

35 Ministerie van Volksgezondheid, Welzijn en Sport (1999), pp. 25; 40-41.

36 Note 1 above.
} 
compensation for damage. Traditionally this was "fault" although there is a clear tendency in many legal systems towards strict liability. In the literature it is claimed that usually some shortcoming on the side of the injurer is required as a basis for a liability in tort. ${ }^{37}$ The idea of a necessary shortcoming may be highly implicit in regimes of strict liability, but may nevertheless be present there as well. A basic rule in tort law is that if the victim can prove that his loss was caused by this wrongful act (in the sense of shortcoming) of the injurer, he can in principle claim full compensation on the basis of tort law. This full compensation is only reduced (to some extent) if the victim himself also contributed to the loss. The essential ideas of liability law are therefore that the victim has a claim to full compensation on his loss if a causal relationship can be proven with a wrongful act. ${ }^{38}$ These ideas can also be found in traditional private insurance schemes that provide compensations for losses. Risk-averse individuals will take out insurance coverage and the insurer will charge a risk-dependent premium.

The starting point for social security is that it provides compensation (e.g., of healthcare expenses or lost income) irrespective of the cause of the illness or disability. Contributory negligence of the claimant in principle does not exclude a claim on compensation in social security law. However, whereas in tort law the principle is full compensation, social security usually provides a compensation limited in time and in amount: Existenzsicherung. Moreover, in social security the financial situation of the victim might play a role in deciding upon the amount of compensation. These redistribution elements are, again, contrary to the basic approach of private insurance and tort law: a victim is, if the specific conditions of tort are met, entitled to full compensation, irrespective of his personal wealth. ${ }^{39}$

Another starting point for social security is the idea of solidarity between citizens. All citizens contribute to the social security system based on their income. Thus, those in employment pay for those who, for a variety of reasons, cannot work (and hence do not contribute to social security) and receive social security benefits. This contrasts rather sharply with (liability) insurance. It is sometimes said that within insurance there is solidarity between all the insured. That, however, is a different type of solidarity than the one in social security. The solidarity referred to in private insurance is only a system of risk-spreading whereby all insured (via premium payments) contribute to the loss when the risk occurs with one particular insured. However, since premium is in principle risk-based in insurance, bad risks should pay more than good risks. Risk differentiation is therefore the leading principle in insurance, not the type of income-dependent solidarity, which is the case in social security. ${ }^{40}$

When one looks at Dutch regulations concerning compensation for pharmaceuticals one has to remember that two separate systems exist. The system under the Health Insurance Act, described above, is, as was indicated, clearly solidarity-based and the registration with a health insurance fund is mandatory. That system, to which 64 per cent of the Dutch population has to subscribe, is not related to the principles of private insurance.

The situation is different with regard to the private insurance system. Although the private insurers are, as a result of regulation, forced to provide a so-called standard insurance for which the premium is determined by the government, they go a lot further than that in

37 For further details see Klosse and Vonk (2000), p. 200.

38 Hartlief (1997), pp. 26-28.

39 Ibid., pp. 28-29.

40 See Faure (1998), pp. 265-93. 
providing coverage. Private insurances are indeed based on the idea of risk differentiation, meaning that in principle, as we will indicate when we discuss financing, bad risks pay more than good risks.

\subsection{An analysis of the system of finance}

Let us now consider the question of the extent to which the financing of the compensation system for pharmaceuticals can be considered efficient. We will address this question by, once more, comparing the social healthcare system with private insurance.

Private insurance starts from the simple assumption that demand for insurance arises from risk-averse individuals. These risk-averse individuals demand insurance cover, which is provided by insurers in competitive insurance markets. They aggregate similar but nonrelated risks into risk pools and are able to accept these risks because they can spread them over a large number of cases. To control moral hazard and adverse selection the insurer distinguishes risks according to the individual risk posed by the particular insured party. Hence, a system of risk differentiation is applied whereby narrow risk pools are construed in such a way that the premium charged corresponds with the risk posed by the average insured in that particular pool. An important feature of private insurance is, therefore, that the price charged, i.e., the premium, corresponds with the risk. The insurer often charges a higher premium than the fair price. This depends on his market position and administrative costs. Depending upon the degree of risk aversion of the insured party and the premium charged, the individual demands insurance cover for specific risks to which he is averse.

Social security in general differs from the situation sketched above in many respects. Healthcare is provided, at least as far as basic needs are concerned, either totally free of charge or with a modest deductible to almost all citizens. The legal systems may differ with respect to who can benefit from social security and with respect to the payment system. In some countries healthcare is simply provided for free; in other countries the patient must pay, but can recover the expenses from his insurer or, in other cases, the (social) insurer pays the cost of healthcare directly. ${ }^{41}$ Within a social security system equal access to healthcare is usually essential.

The premium paid for social security is generally income dependent. Hence, although there may be large differences between countries, some essential features of healthcare provided through social insurance are consistent: contrary to the situation under private insurance, there is no risk differentiation, but there is a principle of solidarity between good and bad risks. ${ }^{42}$ In addition, the premium is not dependent on risk but on income.

With respect to compensation for pharmaceuticals in the Netherlands the crucial question (from an efficiency perspective) is obviously in what way the systems provide adequate incentives for demand. ${ }^{43}$ If one assumes that demand for pharmaceuticals is

41 The way the system is organized may be dependent on the particular legal system. For an introduction to the social security system in Europe see Pieters (1993).

42 Mitchell and Zeldes (1996, p. 11) also consider redistribution and national risk-sharing as essential features of the social security system.

43 Here one must also think of the problem of demand generation: this may occur when drug prescribers (such as general pracitioners and specialists) generally prescribe drugs more often than is strictly necessary or in excessive amounts, e.g., as a result of visits by medical representatives of the pharmaceutical industry. 
elastic $^{44}$ and can thus be influenced, at least to some extent, by the price charged for pharmaceuticals, then traditional insurance economics would indicate that some device should be introduced to control moral hazard. Traditional private insurance schemes usually use a system of risk-dependent premium-setting and hence charge higher premiums when demand for pharmaceutical products increases. This could also be done ex post on the basis of a system of experience rating. Such a mechanism of risk-dependent premium-setting is obviously only possible in private insurance and not in social insurance, the latter being based on an income-dependent premium. If this is related again to the financing of the costs of pharmaceutical products in the Netherlands it may be said that the HIA system (covering over 64 per cent of all patients) is financed on a flat-rate basis, and not related to risk, whereas in private insurance some risk differentiation is applied.

However, the moral hazard risk inherent in any insurance system may not only be controlled by risk differentiation, but also by partially exposing the insured party to risk. In traditional insurance systems this is done through the so-called deductible. In the Netherlands this deductible exists in private insurance. The government experimented briefly with a system of limited charges under the social insurance system (see section 3.2.2) but this experiment lasted only one year.

In sum, although the regulatory framework, in the Netherlands, to a large extent limits the possibilities insurers have to relate the premium and the insurance scheme to the risk, one can see that at least some devices, such as the deductibles, were introduced to control the potential risk of excess demand.

Most of the inefficiencies of the current compensation system for pharmaceuticals in the Netherlands probably do not result from a lack of effective controls on overconsumption, but may result from inefficiencies on the supply side. Indeed, serious questions can be asked with respect to the competitiveness of the market for pharmaceuticals and the possibilities for the consumer to purchase cheaper generic drugs, which have the same medical effects. The least one can say is that the current insurance system does not provide incentives to the patient to purchase the cheapest pharmaceuticals possible. However, patients can obviously only purchase optimally priced pharmaceuticals if these are also offered on a competitive market. Precisely the current price structure of pharmaceuticals and the role that the pharmacist plays in this respect casts doubt on the competitiveness of the market.

\subsection{Optimal prices for pharmaceutical products sold via pharmacies?}

So far we have critically reviewed how the social and private healthcare regimes influence the demand for pharmaceuticals. This brought us to the conclusion that there is more scope for an efficient risk differentiation in private healthcare insurance than in social insurance schemes. However, as indicated at the end of last section, most of the inefficiencies of the current Dutch system do not follow from excess demand for pharmaceuticals but from inefficiencies on the supply side.

Indeed, taking a brief look at the extensive regulatory framework of drug prices in the Netherlands it immediately becomes clear that in practice price competition is almost excluded for pharmacists. Pharmacists receive a fixed amount per prescription (see section 2.2): it does not matter whether a pharmacist gives a patient (time-consuming) advice about a

${ }^{44}$ Of course this proposition does not apply for "life-saving" pharmaceuticals. 
drug or just hands it out like a normal retailer. It also does not matter whether it concerns an own preparation or not. It is obvious that this tight price regulation is hardly of benefit to the consumer: there is no possibility of choice between good service/higher price and bad service/ lower price. Given the present tariff structure, pharmacists may even be inclined to sell as many prescribed drugs as possible while giving little or no advice, because they do not get extra money for these time-consuming services. Hence, the current structure of price regulation in the Netherlands may have adverse effects on pharmacists' incentives to increase the quality of their services. Even though the Dutch Government is willing to change the situation, it is still not clear when and how this could be done. ${ }^{45}$

If this regulation of pharmacists' fees is not in the public interest, could it be in the private interest? At first glance the answer is no, because it seems that no one benefits from this fixed fee system: consumers often do not receive the right amount of information about the drugs they take and pharmacists do not get paid for giving advice, warning about possible interactions with other drugs and preparing their own medicines. Moreover, the government (more specifically, the Health Charges Board) has to compute the fixed fee every year. The current tariff structure can therefore most probably be seen as a result of competition among different interest groups, notably pharmacists, insurers, prescribers (general practitioners and specialists), the pharmaceutical industry, wholesalers of drugs and patient organizations. ${ }^{46}$ On the other hand, if one has to identify one group that benefits from this structure, it is most likely the pharmaceutical profession, because theory predicts that tariff regulation without competition might lead to monopoly profits. However, government (tariff) regulation to some extent limits these profits, that is, the government determines the fixed fee on prescribed drugs (the Health Charges Board), after consultation with the pharmaceutical profession. Given the latter's monopoly position, the regulation of fees is in their interest since they have a guaranteed income for every drug they sell, irrespective of the quality of the service they provide. However, it is possible that in a system of unregulated drug prices, profits could be even higher. In this respect, it is possible that the Dutch tariff regulation system (the fixed fee) somewhat limits profits in comparison with an unregulated system.

\subsection{Prices of pharmaceuticals and insurability}

We have shown that the compensation system for the purchase of pharmaceutical products is heavily regulated, at least as far as the HIA system is concerned. Since the public budget is to a large extent responsible for paying the cost of pharmaceuticals, one could ask the question whether it is possible to reduce a tendency towards excess demand. Indeed, one could predict that, if pharmaceutical prices did not vary in function of demand and if patients were fully reimbursed for drug purchases, inefficiencies may arise. However, it is striking that some mechanisms coming from the traditional private insurance scheme, such as deductibles, are introduced to control demand, obviously as a result of increasing pressures on the public budget. These deductibles are not exclusive to the private insurance system, but also exist in the social insurance system. Moreover, in private insurance a risk-dependent premium-setting

45 In 1999 as many as three different reports were written about the future of the Dutch policy with respect to the market for medicines. A cabinet opinion on these reports was published on 14 April 2000.

46 For an introduction to and an analysis of the "private interest hypothesis" in the so-called Economic Theory of Regulation, see Stigler (1971), Posner (1974) and Pelzman (1976). For an analysis of competition between interest groups, see especially Becker (1983). 
is (to some extent) possible. In social insurance this is not so much the case, since the premium is not risk-based, but largely income-based.

As is the case with all systems of publicly financed healthcare, public authorities will have to control the supply side as well. One aspect of this supply is the role of the pharmacist in delivering pharmaceutical products. As already indicated, the pharmacist receives a fixed fee for any prescribed drug sold, no matter what its price. In section 2.2 we saw that incentive mechanisms were introduced to encourage pharmacies to sell parallel-imported or generic drugs instead of proprietary drugs. Indeed, these incentive measures were obviously necessary since a fixed fee system for pharmacists could hardly be expected to act as an incentive to provide optimal medication at the lowest possible price. However, as shown above, this incentive measure has not worked very well and has now more or less been abandoned.

On this basis, we can conclude that pharmacists are unlikely to collaborate with the government to provide optimal pharmaceuticals at the lowest possible prices. This has to do with the lack of competition between pharmacists, quantitative restrictions and the fixed fee, which all provide excellent income guarantees to pharmacists, but very little incentive to cooperate with the government to reduce the public health budget. This should come as no surprise, and it has been shown in another article that the regulation of pharmacies both in the Netherlands and in Belgium can to a large extent be explained as promoting private rather than public interests. ${ }^{47}$

The social health insurance system as it currently stands will only be able to work in the long run if prices of pharmaceuticals can be controlled. As described above (in section 2.1) this is already the case. All drugs supplied by pharmacies are listed in the so-called taxe, which in effect regulates price. Since the pharmacist only receives a fixed fee for the drugs he or she delivers on prescription (and is not paid as a retailer) the pharmacist simply passes on the full purchase cost of the drug to the consumer and thus to the social or private healthcare system. Since a large part of drug prices are compensated by the public health care system, one can expect the government to intervene in drug pricing. This was the aim of the Drug Prices Act, which gave the power to the Minister of Public Health to fix maximum prices for registered drugs. Moreover, Dutch price regulation involves not only a Drug Prices Act, but also the (in)famous Drugs Reimbursement System (DRS) discussed above. It is understandable that, as a result of the DRS, insurability concerns (the amount of reimbursement for a drug) become of primary importance for the price of a drug. Indeed, the Minister brings together mutually interchangeable drugs in a cluster and fixes a reimbursement limit per cluster. This reimbursement limit is not that flexible, but can be adapted to prices, as indicated above (section 3.2.3). However, the literature indicates that this reimbursement system has a clear influence on the price strategy of the pharmaceutical industry. The reason is obvious: if industry were to set prices higher than the reimbursement limit, patients would have to pay a part of the price for the pharmaceutical product, which would obviously decrease demand. ${ }^{48}$

The simple conclusion therefore is that reimbursement via the insurance system has the effect of lowering drug prices. However, this system is not very flexible and seriously restricts

47 Philipsen and Faure (2002).

48 In their reports of 1999, the Dutch Ministry of Economic Affairs and the Ministry of Public Health are rather critical with respect to the DRS as well: see MDW (1999, pp. 67-68) and Ministerie van Volksgezondheid, Welzijn en Sport (1999, p. 67). 
competition. Both the Drug Prices Act and the Drugs Reimbursement System leave very little room for competition, which may in the end result in higher prices for drugs.

If one views the extremely complex regulatory system concerning the sale and pricefixing of drugs in the Netherlands it becomes clear that it is for reasons of guaranteeing insurability that this complex system arose. However, as already mentioned, the current regulatory system can be questioned on public interest grounds. The concurrent application of various restrictive regulations may seriously limit competition and cause inefficiencies. Indeed, not only are drug prices and reimbursement limits regulated, but so are the retailing of drugs (pharmacies enjoy a monopoly on most drugs) and the pharmacists' fixed fee. To some extent some form of regulation may be unavoidable in social insurance schemes. However, the question always arises, with a view to proportionality, whether the contents of the regulation do not go further than necessary to reach a certain goal. Private interest theory may explain the regulation as one mainly serving the purposes of interest groups. However, it is not totally clear who the main beneficiaries of this gain are. To some extent the pharmacists obviously benefit from restrictions on competition on the number of pharmacies. Regulation therefore seems to be at least to some extent serving their interests. ${ }^{49}$ It is less clear with regards to the system of price regulation. Price fixing, leading to a restriction on competition, may obviously be in the interest of existing pharmaceutical producers. The same may be true for the Drugs Reimbursement System, although this system seems clearly to be benefiting insurance as well, if one considers the fact that all private insurers follow the DRS rules (voluntarily). One may expect that this complex regulation concerning prices and reimbursement of pharmaceuticals is the result of competition for regulation between different interest groups, as predicted by Becker. ${ }^{50}$ Indeed, one notices that healthcare insurers have an influence on the fixing of the DRS reimbursement limits. They are not yet formally involved, but can advise and hence lobby for lowering the reimbursement limits. ${ }^{51}$ Moreover, the complex price regulations, described in section 2 of this paper, have also made clear that it is extremely difficult for new pharmaceutical products to enter the market, notwithstanding the incentive measures that are supposed to promote this goal. ${ }^{52}$ If one effect of regulation were to protect existing producers on the market (by making entry difficult), then this would provide evidence for Stigler's hypothesis that industry seeks to use regulation to create barriers to entry. ${ }^{53}$

\section{Concluding remarks}

In this paper we have focused on the interrelationship between insurance as a tool for compensating for the costs of pharmaceutical products and prices and regulation concerning pharmaceuticals. We have examined the regulation and financing of pharmaceuticals in the Netherlands. Some of the findings are applicable to other regulatory schemes.

We have focused on the supply side of pharmaceuticals by asking what regulatory measures are taken before a pharmaceutical product reaches a consumer. The regulatory scheme seems to be overwhelmingly complex with regulations affecting the price of drugs, admittance of drugs to the market, the delivery of drugs and pharmacists' fees. Within the

\footnotetext{
49 See also Philipsen (2000).

50 Becker (1983), pp. 371-400.

51 See also MDW (1999, p. 68).

52 See also section 3.2.3.

53 Stigler (1971), pp. 3-21.
} 
limited scope of this paper, we have not even been able to deal with all the regulations applicable to this branch of the industry. The result is obviously a system where complex regulations leave little room for market forces.

The same seems to be true to some extent on the demand side, which is heavily influenced by the financing system. There are basically two different systems: private and social insurance. The differences between these two systems are important, since they depart from different principles. Private insurance is based on risk differentiation and risk-dependent premium-setting, whereas social insurance is based on the provision of basic needs via public mechanisms with basically income dependent premiums. ${ }^{54}$ We have shown that the Netherlands has a mixed system (like many other countries) ${ }^{55}$ of social health insurance, where principles of social insurance apply alongside a private insurance scheme (mostly for the higher income groups). The latter provides more scope for applying principles of insurance economics, although also in the social insurance scheme, a tendency can be seen to introduce incentive measures to control demand.

Probably mostly as a result of the large dependence on public budgets, there is increasing pressure to reduce public health care expenses. The cost of pharmaceuticals may certainly not be considered the largest problem in that respect, but the fact that the public budget largely intervenes to compensate for the cost of pharmaceuticals provides the government with an incentive to control prices. The result is a complex system of regulations for drug prices, pharmacies and insurance reimbursement limits. This shows that from the moment one wishes to control the supply of pharmaceutical products a highly complex regulatory structure apparently becomes necessary, given the many players in this field.

As such one could clearly make a public interest argument in favour of some form of regulation of pharmaceuticals, the most important one of course being related to public health. An uncontrolled provision of pharmaceuticals without any ex-ante control may lead to uncontrolled externalities. Producers could even imagine "hit and run" strategies since harmful effects of certain pharmaceutical products may only arise after many years. ${ }^{56}$ Moreover, Akerlof's famous problem of asymmetric information may lead to a market for lemons. ${ }^{57}$ Hence, this asymmetric information problem may warrant a regulation of services provided by pharmacies. However, as is often the case, there may originally be a reason for regulatory intervention (market failures such as asymmetric information or externalities), but one can often see in practice that the contents of the regulation cannot meet a proportionality test. ${ }^{58}$ In other words: they go much further than is required to cure market failures. Inefficiencies may be the result. If one views the current regulatory system of the provision and pricing of pharmaceuticals in the Netherlands, the result seems to be indeed an inefficient overregulation. However, it is difficult to indicate precisely how large these inefficiencies are. This would require empirical research, e.g., into the pricing strategy of pharmaceutical companies and the corresponding demand. Within the scope of this paper we have limited ourselves to qualitative research on the contents of regulations. ${ }^{59}$ Already this points to various inefficiencies.

54 For these differences see Faure (1998, pp. 265-93).

55 Note 41 above.

56 The problem of "latency" (long time lapse between a tort and damage) has often been advanced in the literature as the reason for relying on safety regulation. See Shavell (1984).

57 Akerlof (1970).

58 See also Philipsen and Faure (2002).

59 An interesting point of further research would therefore be to include also quantitative elements. 
However, one may reply that the goal of regulation in the Netherlands, concerning the maximum price of drugs, is not only to promote social welfare, but also to achieve some redistribution. Indeed, the whole social insurance scheme with its income-based premiums may only be affordable if prices of drugs are somehow controlled. Thus this redistribution may warrant a regulatory intervention. But again, the question can be asked whether the current complexity of regulation is the best way to reach this public policy goal. One could even wonder whether without price regulation and with more competition enabling newcomers to enter the market more easily, prices for drugs may not actually be a lot lower.

Some of the regulations described may actually be the result of lobbying by specific interest groups (serving the interests of existing firms on the market by creating barriers to entry) or the result of competition between various interest groups (pharmaceutical producers, insurers, bureaucrats and pharmacies). The fact that regulation today may create substantial profits for some interest groups (which is often the case with regulation aiming at redistribution) also shows that it may be very difficult to change regulation towards more efficient schemes. Some of the recent attempts in the Netherlands, e.g., to introduce incentive measures, have failed, as has been shown. Indeed, public choice theory has always shown that existing regulatory schemes provide benefits to some groups unavoidably leading to political pressures not to take these benefits away from them. ${ }^{60}$ It may therefore be highly difficult to change the system.

\section{REFERENCES}

AKERLOF, G., 1970, “The Market for Lemons: Quality, Uncertainty and the Market Mechanism”, Quarterly Journal of Economics, pp. 488-500.

BECKER, G.S., 1983, “ATheory of Competition Among Pressure Groups for Political Influence”, Quarterly Journal of Economics, 98, pp. 371-400.

BOGIN (Bond van de Generieke Geneesmiddelenindustrie Nederland), 1999, Marktwerking, Deregulering en Wetskwaliteit: Eindelijk ook in de geneesmiddelensector?, Bogin Position Paper, July.

FAURE, M., 1998, "The Applicability of the Principles of Private Insurance to Social Health Care Insurance seen from a Law and Economics Perspective", The Geneva Papers on Risk and Insurance, 23, pp. 265-93.

HARTLIEF, T., 1997, Ieder Draagt Zijn Eigen Schade: Enige opmerkingen over de fundamenten van en ontwikkelingen in het aansprakelijkheidsrecht. Deventer.

KLOSSE, S. and VONK, G., 2000, "De Betekenis van het Recht voor de Toekomst van de Sociale Zekerheid”, in S. Klosse (ed.), Sociale Zekerheid: Een ander gezichtspunt.

KNMP (Koninklijke Nederlandse Maatschappij ter bevordering der Pharmacie), 1998, Pharmacy in the Netherlands: Special issue 1998. The Hague.

MDW (Project Markwerking, Deregulering en Wetgevingskwaliteit), 1999, Rapport Werkgroep Geneesmiddelen. Den Haag, December.

MINISTERIE VAN VOLKSGEZONDHEID, WELZIJN EN SPORT, 1999, Een Helder Recept: Bevindingen en adviezen van de Begeleidingscommissie Uitvoering Geneesmiddelenbeleid. Den Haag, October.

MINISTERIE VAN VOLKSGEZONDHEID, WELZIJN EN SPORT, 2000, Gezondheidszorg in Sociaal-Economisch Perspectief. Den Haag, September.

MINISTERIE VAN VOLKSGEZONDHEID, WELZIJN EN SPORT, 2002, Ziektekostenverzekeringen in Nederland: Stand van zaken per 1 januari 2002. Den Haag, January.

MINISTRY OF HEALTH, WELFARE AND SPORT, 1998, Health Insurance in the Netherlands (4th edn). The Hague, June.

MITCHELL, O.S. and ZELDES, S.P., 1996, Social Security Privatisation: A structure for analysis. Cambridge.

PELTZMAN, S., 1976, “Toward a More General Theory of Regulation”, Journal of Law and Economics, 19, pp. 211-40.

60 Van der Heijden (1983). 
PHILIPSEN, N.J., 2000, “A Private Interest Analysis of Regulation by and of Pharmacists in the Netherlands”, paper presented at the 17th Annual Conference of the European Association of Law and Economics (Ghent, 16 September 2000), Maastricht.

PHILIPSEN, N.J. and FAURE, M.G., 2002, “The Regulation of Pharmacists in Belgium and the Netherlands: In the Public or Private Interest?", Journal of Consumer Policy, 2, pp. 155-201.

PIETERS, D., 1993, Introduction into the Social Security Law of the Member States of the European Community(ed). Deventer.

POSNER, R.A., 1974, “Theories of Economic Regulation”, Bell Journal of Economics and Management Science, 5, pp. $335-58$.

RAAD VOOR DE VOLKSGEZONDHEID EN ZORG (RVZ), 1998, Farmaceutische Zorg door Arts en Apotheker, bijlage 7, Zoetermeer, March, pp. 95-98.

SFK (Stichting Farmaceutische Kengetallen), 1999, Facts and Figures 1999. The Hague, September.

SFK (Stichting Farmaceutische Kengetallen), 2001, Data en Feiten 2001. Den Haag, May.

SHAVELL, S., 1984, "Liability for Harm versus Regulation of Safety”, Journal of Legal Studies, pp. 357-74.

STIGLER, G.J., 1971, “The Theory of Economic Regulation”, Bell Journal of Economics and Management Science, Vol. 2, pp. 3-21.

VAN DER HEIJDEN, P.F., 1983, "Privatisering van de Sociale Zekerheid: Financiële consequenties en politieke haalbaarheid", in F.A.J. Van den Bosch and C. Peterson (eds.), Economie en Arbeidsongeschiktheid: Analyse en beleid. Deventer, pp. 215-24. 